\title{
A photographic method for quantifying surface defecation
}

\author{
Amy Frances MacRae* and Sarah Ann Woodin \\ Belle W. Baruch Institute of Marine Biology and Coastal Research, University of South Carolina, \\ Columbia, South Carolina, USA
}

\begin{abstract}
A non-destructive method is presented for quantification of deposition by infauna which defecate on the sediment surface. The method is particularly appropriate for infauna which produce unconsolidated feces in a fine layer on the sediment surface. Using Clymenella torquata, a depositfeeding maldanid polychaete, results of the non-destructive photographic method are compared to those of a destructive collection technique. The results are similar. The photographic method is especially advantageous when amounts of defecation need to be measured over short time intervals.
\end{abstract}

\section{INTRODUCTION}

Many interactions among organisms living within marine sediments are indirect, involving physical or chemical alteration of sediments by infauna, rather than direct contact between individuals. Such sediment-mediated interactions can occur within a species, between 2 species, or among many species. The interactions often depend on population densities per sediment volume (Rhoads and Young, 1970, 1971; Woodin and Jackson, 1979; Peterson and Andre, 1980; Brenchley, 1981; Wilson, 1981, 1983; Rhoads and Boyer, 1982). Bioturbation is one such density-dependent interaction. Bioturbation of marine sediments is a spatially and temporally non-random process that could have a large, predictable effect on infauna. For example, organisms that deposit feed at depth and defecate on the surface alter sediment texture, grain size-composition, pore water content and organic content (Rhoads, 1967, 1970, 1973; Myers, 1977; Rhoads and Boyer, 1982). In addition, the physical process of depositing sediment on top of or near surface deposit feeders may alter their settlement, growth, behavior, reproduction and lifespan (Brenchley, 1978, 1981; Weinberg, 1979; Wilson, 1981, 1983).

\footnotetext{
- Present address: Department of Molecular and Population Genetics, University of Georgia, Athens, Georgia, USA Contribution no. 559 of the Belle W. Baruch Institute of Marine Biology and Coastal Research
}

Unfortunately, deposit feeders do not usually produce feces which are easily collected so estimations of rates of deposition have been dependent upon one of the following: (1) attachment of a collection device to the tube of the individual, (2) attachment of a device to the defecation area of the individual to monitor activity cycles, or (3) deposition of a contrast substance on the area of deposition. The first 2 methods incorporate the potential error of the effect of the device (e.g. Wells, 1951; Nichols, 1974; Dobbs, 1983). The second assumes that amounts deposited per event are already known and are predictable so that only activity frequency need be measured. Deposition is however often variable in amount (Cadée, 1976) as well as frequency (Dobbs, 1983). The third method averages deposition over a relatively long time period so that the deposited material is easily collected or the burial rate is determined by a method such as radiation counting of $\mathrm{Pb} 210$ or $\mathrm{Cs} 131$ (Fisher, 1982). Method 3 also causes disturbance during collection of the material. This paper describes a modification of Method 3 which allows short-term quantification of deposition without collection for organisms which produce feces with little vertical relief on the sediment surface.

\section{MATERLALS AND METHODS}

Clymenella torquata (Maldanidae) is a tube-dwelling, sub-surface deposit feeder which lives anterior end down. C. torquata manipulates and ingests sedi- 
ment at depth. It produces feces which are discharged into the water column. These rain down near the tube opening, forming a fine covering on the sediment surface. $C$. torquata was chosen for this study because it is a common deposit feeder with unconsolidated feces. Also, activities of maldanids are known to affect negatively other much smaller tube builders (Weinberg, 1979; MacRae, 1983).

Experimental cylindrical cores $\left(50.3 \mathrm{~cm}^{2}\right.$ by $25 \mathrm{~cm}$ high) were filled with sediment that had been frozen, thawed and passed through a $1.0 \mathrm{~mm}$ sieve to rid it of tubes and dead macrofaunal organisms. Cores were placed in a tank $(107.5 \times 49.5 \times 34.5 \mathrm{~cm}$ deep $)$ filled with aerated $34 \% \mathrm{~S}$ seawater. Core surfaces were covered by $3.5 \mathrm{~cm}$ of seawater.

On Day 0 maldanids were introduced into cores that had been submerged in seawater for $24 \mathrm{~h}$. The maldanids had been collected the day before. Treatments included 4 maldanid densities; each treatment had 3 replicates. Cores were arranged in a randomized design.

There were cores with 1, 2, 4 and 6 maldanids (1X, $2 \mathrm{X}, 4 \mathrm{X}$ and $6 \mathrm{X}$ densities, respectively). These were used to quantify maldanid fecal production over time. There were also 3 manipulation control cores with 2 maldanids each, used to test for effects of alternate-day collections of maldanid feces on maldanid activities at the $2 \mathrm{X}$ density. Densities of maldanids in cores corresponded to the following field densities: $1 \mathrm{X}=$ $220 \mathrm{~m}^{-2}, \quad 2 \mathrm{X}=439 \mathrm{~m}^{-2}, \quad 4 \mathrm{X}=878 \mathrm{~m}^{-2}, \quad 6 \mathrm{X}=$ $1316 \mathrm{~m}^{-2}$. Actual field densities of maldanids were $216 \mathrm{~m}^{-2}$. All of the maldanids used in these experiments were dried and weighed at termination (mean dry wt. $16.2 \mathrm{mg}, \mathrm{SD} 5.4$ ). All individuals defecated within the first $24 \mathrm{~h}$ of the experiment.

On Day 1 after draining the tank to near the level of the core surfaces, a fine layer $(<.5 \mathrm{~mm})$ of calcium carbonate powder (grain size $<.25 \mathrm{~mm}$ ) was sprinkled onto all core surfaces with a flour sifter. Use of the flour sifter allowed us to sprinkle a fine even layer on the core surface. This permitted visualization of maldanid feces against a white background. On Days 3, 5, 7 and 9 , the following procedures were followed. At the same time on each of those days, the airstones were turned off and the tank water drained to near the level of the core surfaces. The core surfaces were photographed with a $35 \mathrm{~mm}$ camera and strobes. Maldanid feces were then collected with a $100 \mathrm{ml}$ rubber bulb pipette. (Feces were not collected from the manipulation control cores until termination of the experiment.) Finally a new thin layer of calcium carbonate was added and the tank refilled. After all observations on Day 5 were completed, the seawater in the tank was completely replaced. At experimental termination (Day 10), the accumulated maldanid feces were collected from the manipulation control cores with a $100 \mathrm{ml}$ rubber bulb pipette, down to the deepest calcium carbonate layer. The feces were dried to constant weight and weighed. The area of the core surface covered by maldanid feces was determined from the projected negative with a digitizer connected to a minicomputer (for details see Wethey, 1983).

The data were analyzed by a repeated-measure analysis of variance (ANOVA) because the same individuals were observed repeatedly during the experiment (Winer, 1971). Consequently, observations of the same core made on different days were not independent. All data were transformed by the $\log (y+1)$ transform to meet assumptions of the ANOVA. If the results of the ANOVA indicated that there were significant differences $(\mathrm{p}<0.05)$, multiple Bonferroni tests were used to determine which treatments were significantly different from one another (family confidence coefficient 0.95) (Neter and Wasserman, 1974).

\section{RESULTS AND DISCUSSION}

The study addressed 2 methodological questions: (1) Does fecal collection significantly affect fecal production? (2) Are the results of a non-destructive photographic method similar to those of a destructive fecal collection method? Collection of feces did not significantly affect fecal amounts (ANOVA: $\mathrm{F}=1.13$; df $=$ $1,4 ; \mathrm{MSE}=0.0101 ; \mathrm{p}>0.34)$. Thus fecal collection at these rates does not influence defecation amounts by Clymenella torquata.

To ask if maldanid fecal production varied with maldanid density or with time and whether the results for direct collection of feces versus photographic documentation were similar, 2 repeated measures ANOVAs were performed, one on fecal weights and one on fecal areas. Both sets of data were from the same cores. The fecal area and fecal collection methods showed sirnilar treatment effects (Bonferroni tests, Tables $1 \mathrm{~B}$ and $2 \mathrm{~B}$ ). Maldanid fecal weights increased with increasing maldanid density (Table 1 B). Maldanid fecal areas also increased with density (Table 2 B). Using the fecal collection method, fecal weights for the $2 \mathrm{X}$ and $4 \mathrm{X}$ treatments were not significantly different from those for the $1 \mathrm{X}$ or $6 \mathrm{X}$ treatments although values for $1 \mathrm{X}$ and $6 \mathrm{X}$ were significantly different from one another (Table $1 \mathrm{~B}$ ). Using the photographic method, fecal areas for the $2 \mathrm{X}$ and $4 \mathrm{X}$ treatments were not significantly different from one another but they were from both the $1 X$ and the $6 X$ treatments (Table 2 B). As with the fecal collection method, fecal areas for the $1 \mathrm{X}$ and the $6 \mathrm{X}$ treatments were also significantly different (Table $2 \mathrm{~B}$ ).

Results for the time effect differed for the 2 methods. 
Table 1. Repeated-measures ANOVA on maldanid fecal weights. (A) Repeated-measures design ANOVA on weights of maldanid feces (g). Feces were collected from 3 replicate cores $\left(50.3 \mathrm{~cm}^{2}\right)$ at 4 maldanid densities on Days $3,5,7$ and 9 . MS: mean square, df: degrees of freedom, p: probability value. (B) Back-transformed geometric means (Y) (mg) \pm 1 standard deviation (S.D.) for treatment and time effects. Means with the same letter are not, means with different letters are significantly different from one another (Bonferroni tests, $p<0.05$ )

\begin{tabular}{|c|c|c|c|c|}
\hline \multicolumn{5}{|c|}{ (A) Repeated-measures ANOVA } \\
\hline Source & df & MS & $\mathrm{F}$ & $\mathrm{p}$ \\
\hline Density & 3 & 0.1139 & 8.71 & 0.007 \\
\hline Day & 3 & 0.0109 & 4.98 & 0.008 \\
\hline Density * Day & 9 & 0.0109 & 0.77 & 0.648 \\
\hline \multicolumn{5}{|c|}{ (B) Maldanid fecal weights } \\
\hline Treatment & $1 \times$ & $2 \times$ & $4 \times$ & $6 \times$ \\
\hline Y & $0.37 \mathrm{a}$ & $0.99 \mathrm{ab}$ & $1.44 \mathrm{ab}$ & $2.43 b$ \\
\hline S.D. & $(0.12,0.68)$ & $(0.61,1.47)$ & $(0.89,2.15)$ & $(1.51,3.69)$ \\
\hline \multicolumn{5}{|l|}{ Time effect } \\
\hline Day & 3 & 5 & 7 & 9 \\
\hline $\mathrm{Y}$ & $0.94 a$ & $1.44 \mathrm{~b}$ & $1.11 \mathrm{ab}$ & $1.30 \mathrm{ab}$ \\
\hline S.D. & $(0.41,1.66)$ & $(0.54,2.88)$ & $(0.31,2.39)$ & $(0.55,2.42)$ \\
\hline
\end{tabular}

The fecal collection method indicated that Days 3 and 5 were significantly different from one another (Table $1 \mathrm{~B}$ ). The fecal area method did not indicate a significant time effect (Table $2 \mathrm{~B}$ ).

The advantage of the photographic method is that observations can be made over much shorter time periods than can be used with the collection technique. Woodin, for example, has used observation periods as short as $2 \mathrm{~h}$ for single maldanids (Woodin, 1984). For organisms which produce unconsolidated feces (e.g. Clymenella torquata) collecting fecal material in small amounts is difficult. The photographic method is one solution to quantification of small amounts of feces. It also avoids the decrease in sediment volume which long experiments with regular collections of feces entail. The fecal collection method may be more accurate than the photographic method when measuring defecation rates of organisms that produce tall, unconsolidated mounds (e.g. pectinariid polychaetes) or those that produce fecal castings with irregular vertical contours (e.g. arenicolid polychaetes).

For rates of sediment burial the photographic method is inappropriate because the thickness of the new sediment layers cannot be measured from above. For short-term rates of deposition and relative activities of organisms the photographic method is preferable to destructive or radioactive marker techniques.

Table 2. Repeated-measures ANOVA on maldanid fecal areas. (A) Repeated-measures design ANOVA on area of core surface $\left(50.3 \mathrm{~cm}^{2}\right)$ covered by maldanid feces. The area of surface covered was estimated from 3 replicate cores at 4 maldanid densities on Days 3, 5, 7 and 9. (B) Back-transformed geometric means ( $Y$ ) $\left(\mathrm{mm}^{2}\right) \pm 1$ S.D. for treatment and time effects. Means with the same letter are not, means with different letters are significantly different from one another (Bonferroni $t$-test, $p<0.05$ )

$\begin{array}{lcccc}\text { (A) Repeated-measures ANOVA } & & & & \\ \text { Source } & \text { df } & \text { MS } & \text { F } & \text { P } \\ \text { Density } & 3 & 1.4616 & 5.69 & 0.022 \\ \text { Day } & 3 & 0.0425 & 1.24 & 0.318 \\ \text { Density - Day } & 9 & 0.0350 & 1.02 & 0.452\end{array}$

(B) Area of core surface covered by maldanid feces

Treatment effect

Treatment

Y

S.D.

Time effect

Day

Y

S.D.

$1 \times$

$59.4 \mathrm{a}$

$(22.6,156.0)$

3

$168.4 \mathrm{a}$

$(78.5,361,3)$

$2 \times$
$174,9 \mathrm{~b}$
$(106.1,288.2)$
5
$167.8 \mathrm{a}$
$(59.3,474.5)$

$4 \times$
$219.0 \mathrm{~b}$
$33.1,360.3$

7

$154.6 \mathrm{a}$

$(56.2,425.7)$
$6 \times$

$408.4 \mathrm{C}$

$(270.0,617.7)$

9

$212.6 \mathrm{a}$

$(79.6,567.7)$ 
Acknowledgements. We thank Dr. Dennis Allen for his efforts which enabled us to do the experiment at the Baruch Marine Field Laboratory. Financial support for A. MacRae was received from the Marine Science Program, University of South Carolina, ONR grant no. N00014-82-K-645 to D. Wethey, and NSF grant no. OCE81-09596 to S. Woodin. We thank D. Wethey for review of the manuscript.

\section{LITERATURE CITED}

Brenchley, G. A. (1978). On the regulation of marine infaunal assemblages at the morphological level: a study of the interactions between sediment stabilizers, destabilizers, and their sedimentary environment. Ph. D. Dissertation, Johns Hopkins University, Baltimore, Maryland, p. 1-249

Brenchley, G. A. (1981). Disturbance and community structure: an experimental study of bioturbation in marine softbottom environments. J. mar. Res. 39: 767-790

Cadée, G. C. (1976). Sediment reworking by Arenicola marina on tidal flats in the Dutch Wadden Sea. Neth. J. Sea Res. 10: 440-460

Dobbs, F. C. (1983). Monitoring defecation activity of infaunal deposit feeders. Mar. Ecol. Prog. Ser. 12: 47-50

Fisher, J. B. (1982). Effects of macrobenthos on the chemical diagenesis of freshwater sediments. In: McCall, P. L., Tevesz, M. J. S. (ed.) Animal-sediment relations. The biogenic alteration of sediments. Plenum Press, New York, p. $177-218$

MacRae, A. F. (1983). Sediment reworking by the depositfeeder Clymenella torquata: effects on the activities of Spiophanes bombyx (Spionidae: Polychaeta). Unpublished Masters thesis, University of South Carolina, Columbia, South Carolina

Myers, A. C. (1977). Sediment processing in a marine subtidal sandy bottom community. II. Biological consequences. J. mar. Res. 35: 633-647

Neter, J., Wasserman, W. (1974). Applied linear statistical models. Richard D. Irwin, Inc., Homewood, Illinois

Nichols, F. H. (1974). Sediment tumover by a deposit-feeding polychaete. Limnol. Oceanogr. 19: 945-950

Peterson, C. H., Andre, S. V. (1980). An experimental analysis of interspecific competition among marine filter feeders in a soft-sediment environment. Ecology 61: 129-139

Rhoads, D. C. (1967). Biogenic reworking of intertidal and subtidal sediments in Barnstable Harbor and Buzzards Bay, Massachusetts. J. Geol. 75: 461-476

Rhoads, D. C. (1970). Mass properties, stability and ecology of marine muds related to burrowing activities. Crimes, T. P., Harper, J. C. (ed.) Trace fossils. Seel House Press, Liverpool, p. 391-406

Rhoads, D. C. (1973). The influence of deposit-feeding benthos on water turbidity and nutrient recycling. Am. J. Sci. 273: 1-22

Rhoads, D. C., Boyer, L. F. (1982). The effects of marine benthos on physical properties of sediments. A successional perspective. In: McCall, P. L., Tevesz, M. J. S. (ed.) Animal sediment relations. The biogenic alteration of sediments. Plenum Press, New York, p. 3-52

Rhoads, D. C., Young, D. K. (1970). The influence of depositfeeding organisms on sediment stability and community trophic structure. J. mar. Res. 28: 150-178

Rhoads, D. C., Young, D. K. (1971). Animal-sediment relations in Cape Cod, Massachusetts. II. Reworking by Molpadia oolitica (Holothuroidea). Mar. Biol. 11: 255-261

Weinberg, J. R. (1979). Ecological determinants of spionid distributions within dense patches of deposit-feeding polychaete Axiothella rubrocincta. Mar. Ecol. Prog. Ser. 1: 301-314

Wells, G. P. (1951). On the behaviour of Sabella. Proc. R. Soc. Lond. (Ser, B) 138: 278-299

Wethey, D. C. (1983). Intrapopulation variation in growth of sessile organisms: natural populations of the intertidal barnacle Balanus balanoides. Oikos 40: 14-23

Wilson, W. H., Jr. (1981). Sediment-mediated interactions in a densely populated infaunal community: the effects of the polychaete Abarenicola pacifica. J. mar. Res. 39: 735-748

Wilson, W. H., Jr. (1983). The role of density dependence in a marine infaunal community. Ecology 64: 295-306

Winer, B. J. (1971). Statistical principles in experimental design. McGraw-Hill Book Co., New York

Woodin, S. A. (1984). Effects of browsing predators: activity changes in infauna following tissue loss. Biol. Bull. mar. biol. Lab., Woods Hole, in press

Woodin, S. A., Jackson, J. B. C. (1979). Interphyletic competition among marine benthos. Am. Zool. 19; 1029-1043 